\title{
EU Coordination of Serious Cross-Border Threats to Health: The Implications for Protection of Informed Consent in National Pandemic Policies
}

\author{
Hannah VAN KOLFSCHOOTEN* $*$ C]
}

\begin{abstract}
This article discusses the development of a more supranational EU approach to regulate risks of "serious cross-border threats to health" such as pandemic disease outbreaks. It argues that the EU's public health measures to prevent and tackle pandemics could affect individual patients' rights, because the rights of individual European citizens are balanced against the importance of protecting the European community as a whole. This results in a tension between public health and individual rights in the EU, especially with regard to the right to informed consent, a central right in health law. In response to the 2013-2016 Ebola outbreak in West Africa, the EU introduced several preventive and responsive measures in the Member States to prevent the pandemic from spreading to the EU. The case study analysis of Dutch pandemic policies established in reaction to this outbreak shows that national pandemic policies are substantially shaped by EU actions, which has implications for the protection of the individual right to informed consent in the Member States.
\end{abstract}

\section{INTRODUCTION}

In our twenty-first century globalised world, people can travel across borders faster than ever before, which significantly increases the speed and volume of transmission of infectious diseases around the globe. ${ }^{1}$ An infectious disease pandemic has been called the "biggest threat to humanity" and more and more scientists are expressing concern about the world not being at all prepared to handle a major infectious disease pandemic. ${ }^{2}$ Since infectious diseases do not respect borders, an outbreak can only efficiently be countered if countries join forces, both at the European Union (EU) and

\footnotetext{
University of Amsterdam, Amsterdam Law School; email: h.b.vankolfschooten@uva.nl. Many thanks to Mark Flear and Anniek de Ruijter for their helpful comments and suggestions.

1 JC Semenza et al, "Determinants and Drivers of Infectious Disease Threat Events in Europe" (2016) 22 Emerging Infectious Diseases 581 .

2 B Walsh, "The World is Not Ready for the Next Pandemic" (2017) 189 (18) Time Magazine <time.com/magazine/ us/4766607/may-15th-2017-vol-189-no-18-u-s/> accessed 4 December 2019.
} NonCommercial-NoDerivatives licence (http://creativecommons.org/licenses/by-nc-nd/4.0/), which permits non-commercial re-use, distribution, and reproduction in any medium, provided the original work is unaltered and is properly cited. The written permission of Cambridge University Press must be obtained for commercial re-use or in order to create a derivative work. 
international level. ${ }^{3}$ In order to regulate risks of such "serious cross-border threats to health" to ensure a high level of human health, an adequate level of preparedness and response is required. ${ }^{4}$ In view thereof, the EU coordinates Member States to establish so-called "pandemic preparedness and response plans". 5

In the past the EU has taken various "public health measures" to combat severe communicable disease outbreaks such as the 2005 bird flu outbreak (H5N1) and the outbreak of swine flu in 2009 (H1N1). ${ }^{6}$ Although formally the EU's powers are restricted to the coordination of public health threat surveillance and risk assessment, ${ }^{7}$ the EU has assumed a more extensive role in the development of countermeasures. ${ }^{8}$ In response to the 2013-2016 Ebola outbreak in West Africa, the EU took several countermeasures in the Member States to prevent the virus from spreading to the EU. ${ }^{9}$ The development of a more "supranational" EU approach to tackle future pandemics could affect individual patients' rights, because the rights of individual European citizens are balanced against the importance of protecting the European community as a whole. ${ }^{10}$ This seems to constitute a tension between public health and individual rights in the EU. While public health laws and policies seek "to pursue the highest possible level of physical and mental health in the population", ${ }^{11}$ these laws and policies can constrain civil and social rights of individuals in the same population. ${ }^{12}$ This conflict between individual fundamental rights and public health becomes even more evident in public health crises caused by global pandemics such as Ebola. ${ }^{13}$

The right to informed consent is central to health law and policy, as it encompasses the fundamental rights to self-determination and human dignity. ${ }^{14}$ The right to informed consent is unique in the way it is both linked to physical integrity and privacy issues. It relates to consent to medical treatment and participation in clinical trials as well as

\footnotetext{
3 World Health Organisation, "Essential steps for developing or updating a national pandemic influenza preparedness plan" (2018); World Health Organisation, "Guidance for Managing Ethical Issues in Infectious Disease Outbreaks" (2016) p 13.

4 See Art 168 TFEU Decision No 1082/2013/EU of the European Parliament and of the Council of 22 October 2013 on serious cross-border threats to health and repealing Decision No 2119/98/EC [2013] OJ L 293/1, recital (1).

5 The documents are available at European Commission, "Crisis Preparedness and Response" <ec.europa.eu/health/ preparedness_response/overview_en> accessed 4 December 2019.

6 TK Hervey and JV McHale, European Union Health Law: Themes and Implications (New York, Cambridge University Press 2015) p 515; M Flear, Governing Public Health: EU Law, Regulation and Biopolitics (Bloomsbury Academic 2015) p 144; A de Ruijter, EU Health Law \& Policy: The Expansion of EU Power in Public Health and Health Care (Oxford University Press 2019) p 121.

7 See Art 168 TFEU.

8 M Liverani and R Coker, "Protecting Europe from Diseases: From the International Sanitary Conferences to the ECDC” (2012) 37 Journal of Health Politics, Policy and Law 920; Flear, supra, note 6, pp 158-164.

9 R Watson, "EU Appoints Ebola Coordinator" (2014) 349 British Medical Journal.

10 De Ruijter, supra, note 6, pp 47-49.

11 Definition in UN General Assembly, International Covenant on Economic, Social and Cultural Rights, 16 December 1966, United Nations, Treaty Series, vol 993, p 3, Art 12.

12 LO Gostin, "A Theory and Definition of Public Health Law" in Public Health Law Power, Duty, Restraint (Berkeley, University of California Press 2008) pp 4-6.

13 S Moon et al, "Will Ebola Change the Game? Ten Essential Reforms before the next Pandemic. The Report of the Harvard-LSHTM Independent Panel on the Global Response to Ebola” (2015) 386 The Lancet 2204.

14 RR Faden and TL Beauchamp, A History and Theory of Informed Consent (New York, Oxford University Press 1986) pp 4-19.
} 
the sharing of personal (medical) data. ${ }^{15}$ The increasing role of the EU in policies on public health crises brings into question the effect of the EU's choices regarding the balance between public health and individual rights on the protection of the right to informed consent, which may well be impacted by the EU's pandemic countermeasures.

Against this background, the purpose of this article is to examine whether the right to informed consent is adequately safeguarded in the context of EU policy on pandemic preparedness and response in Europe. In order to answer this question, section II introduces the problems that EU Ebola policies may cause for the protection of informed consent in the Member States. Section III provides a short overview of the protection of the right to informed consent in EU instruments. Subsequently, section IV conducts a legal case study on the national response of the Netherlands to the 2013-2016 Ebola outbreak in West Africa. The first part of this section examines both the EU's and the Dutch government's countermeasures in respectively the EU and the Netherlands during the 2013-2016 Ebola outbreak. The second part of this section then analyses the impact of EU coordination on the protection of the right to informed consent at the national level. In this analysis, a distinction is made between de jure and de facto impact, as the legislative competence of the EU is limited in the field of health, and EU health policy rarely articulates national obligations. ${ }^{16}$ From this case study analysis is concluded that the actions taken at the EU level with regard to public health emergencies, even when only of advisory nature, affect national pandemic policies. Following on from this, it is concluded that EU pandemic policies also impact on the protection of fundamental rights in the Member States, informed consent in particular.

\section{INFORMED CONSENT IN EU EBOLA PREPAREDNESS AND RESPONSE POLICIES: IMPACT OF EU COORDINATION ON THE PROTECTION OF HUMAN RIGHTS?}

The haemorrhagic fever Ebola virus disease (Ebola) is often referred to as "the killer virus" due to the average fatality rate of $50 \%$. It spreads via direct contact with bodily fluids of infected persons and materials contaminated with infected fluids. ${ }^{17}$ Unsurprisingly, the widespread outbreak of Ebola in West Africa in December 2013 caused worldwide concern. This resulted in the EU taking several preventive and responsive measures in order to prevent the virus from spreading to EU Member States and causing a large-scale outbreak there. ${ }^{18}$ EU policy regarding communicable disease control is highly scattered through different institutions and actors in the EU, the most important being the European Centre for Disease Prevention and Control (ECDC) and the European Medicines Agency (EMA). ${ }^{19}$ Formally, with regard to

\footnotetext{
15 FK Dankar et al, "Informed Consent in Biomedical Research" (2019) 17 Computational and Structural Biotechnology Journal 463.

16 See Art 168 TFEU; De Ruijter, supra, note 6, pp 1-8.

17 H Ghazanfar et al, "Ebola, the Killer Virus" (2015) 4 Infectious Diseases of Poverty 15.

18 Watson, supra, note 9.

19 HA Elliott et al, "Mapping Communicable Disease Control in the European Union" (2012) 37(6) Journal of Health Politics, Policy and Law 935; De Ruijter, supra, note 6, pp 123-125; Hervey and McHale, supra, note 6, pp 512-517.
} 
serious cross-border threats to health such as pandemics, EU action is limited to carrying out actions to support, coordinate or supplement action by the Member States, adopting incentive measures and issuing recommendations. ${ }^{20} \mathrm{EU}$ pandemic countermeasures taken by these institutions, however, consist of medical countermeasures, surveillance countermeasures and further "soft" countermeasures. ${ }^{21}$ The EU legal framework for health emergency prevention and response is provided for in Decision 1082/2013 (EU Health Threats Decision). ${ }^{22}$

While addressing health emergencies at the EU level may lead to stronger cooperation between Member States which will eventually contribute to a more effective response to pandemic threats, ${ }^{23}$ pandemic preparedness and response policies may have far-reaching implications for the manner in which Member States handle specific health emergencies. ${ }^{24}$ As a result, EU pandemic policies may also affect the protection of individual rights at the national level, specifically the right to informed consent. ${ }^{25}$ In the case of the 2013-2016 Ebola outbreak in West Africa, the EU and Member States introduced multiple pandemic policies in the EU out of precaution. However, few pandemic measures actually had to be taken, since the impact of the Ebola outbreak on the EU territory was limited. ${ }^{26}$ Therefore, the case study on the national response of the Netherlands to the 2013-2016 Ebola outbreak in West Africa focuses on the legal possibility for safeguarding informed consent if national pandemic response measures had been taken in light of the 2013-2016 Ebola outbreak. In spite of the lack of actual implementation of the measures, this case study provides important insights for the effects of EU pandemic policies on the national order, as it shows the willingness of Member States to take certain measures in case of a cross-border health emergency. In order to provide the normative framework to analyse the impact of EU pandemic policies on the protection of informed consent in the Member States, the subsequent sections will elaborate on the scope and extent of the right to informed consent and its protection in the EU.

\section{ThE SCOPE AND THE EXTENT OF THE RIGHT TO INFORMED CONSENT}

The right to informed consent is a central patient right and is strongly protected in a majority of EU Member States. ${ }^{27}$ It is rooted in the idea that sufficient information has to be provided for patients to make autonomous decisions about their bodies.

\footnotetext{
20 Arts 168(1) and 168(5) TFEU.

21 De Ruijter, supra, note 6, pp 130-136; Flear, supra, note 6, pp 158-164.

22 Decision No 1082/2013/EU of the European Parliament and of the Council of 22 October 2013 on serious crossborder threats to health and repealing Decision No 2119/98/EC [2013] OJ L 293/1, Art 2; H Dijkstra and A De Ruijter, "The Health-Security Nexus and the European Union: Toward a Research Agenda" (2019) 8 EJRR 613.

23 WHO, "Essential steps for developing or updating a national pandemic influenza preparedness plan" (2018).

24 De Ruijter, supra, note 6, pp 149-150.

25 ibid.

26 WHO, "Risk of Ebola spreading in Europe is very low: statement by Zsuzsanna Jakab, WHO Regional Director for Europe" (8 October 2014), <www.euro.who.int/en/health-topics/communicable-diseases/pages/news/news/ 2014/10/risk-of-ebola-spreading-in-europe-is-very-low-statement-by-zsuzsanna-jakab,-who-regional-director-foreurope $>$ accessed 4 December 2019.

27 European Commission, "Patients' Rights in the European Union: Mapping EXercise, Final Report" (2016) pp 3-4 $<$ ec.europa.eu/health/sites/health/files/cross_border_care/docs/2018_mapping_patientsrights_frep_en.pdf > accessed 4 December 2019.
} 
The Greek physician Hippocrates first laid the foundation of the right to informed consent in the patient-doctor relationship around $400 \mathrm{BC}$, promoting the voluntary and informed relationship between doctors and patients. ${ }^{28}$ The principle of informed consent was first legally recognised with regard to clinical research and bioethics after World War II in the Nuremberg Code and the Helsinki Declaration, to prevent the horrifying medical experiments performed by Nazi doctors like Josef Mengele from ever happening again. ${ }^{29}$ The use of informed consent in relation to personal data arose later, in response to developing technology and the emergence of "big data". 30

Del Carmen and Joffe have identified five conditions for valid informed consent to medical treatment: voluntarism; capacity; understanding; disclosure; and decision. ${ }^{31}$ Voluntarism assumes the patient to individually form his will, free from coercion or controlling influences. The element of capacity refers to the patient's competence to make a decision. A patient is only said to be capable of making a specific decision if he is capable of making choices, understanding critical information and have sufficient "rational" capacity to comprehend the implications of choices. This also implies legal capability to make decisions. Understanding involves the patient's full comprehension of the provided information and its implications for his personal situation. Disclosure refers to providing the patient with the relevant information in order to fully understand the action, including the character, objective, risks, benefits and alternative options. Decision means the patient has to actively consent to the proposed action. ${ }^{32}$ These five elements can well be used in ascertaining valid informed consent to participate in research, with the additional requirement that the patient's decision is "written, dated and signed". ${ }^{33}$ Furthermore, this interpretation is in accordance with the General Data Protection Regulation's (GDPR) definition of informed consent to the processing of personal (medical) data. ${ }^{34}$

\section{The level of protection of the right to informed consent in the EU}

The right to informed consent with regard to medical treatment, clinical trials and personal medical data is protected in several EU provisions. ${ }^{35}$ In the context of the EU, Article 3 of the Charter of Fundamental Rights of the European Union (CFR),

28 SH Miles, "Hippocrates and Informed Consent” (2009) 374 The Lancet 1322.

29 M Marzano, "Informed Consent" in JF Gubrium et al (eds), The SAGE Handbook of Interview Research: The Complexity of the Craft (Thousand Oaks, SAGE Publications 2012) p 443.

30 S Rudgard, "Origins and Historical Context of Data Protection Law" in E Ustaran et al (eds), European Privacy: Law and Practice for Data Protection Professionals (International Association of Privacy Professionals 2012) pp 5-6.

31 MG del Carmen and S Joffe, "Informed Consent for Medical Treatment and Research: A Review" (2005) 10 The Oncologist 637.

32 ibid. And see J Ahlin, Personal Autonomy and Informed Consent: Conceptual and Normative Analyses (Stockholm, Kungliga Tekniska högskolan 2017) p 16.

33 Regulation (EU) No 536/2014 of the European Parliament and of the Council of 16 April 2014 on clinical trials on medicinal products for human use, and repealing Directive 2001/20/EC (Text with EEA relevance) [2014] OJ L 158/1, Art 29.

34 Regulation (EU) 2016/679 of the European Parliament and of the Council of 27 April 2016 on the protection of natural persons with regard to the processing of personal data and on the free movement of such data, and repealing Directive 95/46/EC (General Data Protection Regulation) [2016] Art 4 (11) GDPR.

35 G Bache et al, "The Defining Features of the European Union's Approach to Regulating New Health Technologies" in European Law and New Health Technologies (Oxford University Press 2013) pp 30-41; Flear, supra, note 6, pp 226-230. 
the right to the integrity of the person, protects informed consent most directly, as it specifically refers to the right to "free and informed consent" in the fields of medicine and biology. ${ }^{36}$ Articles 7 and 8 CFR state that personal data must be processed on the basis of "consent". Furthermore, the right to informed consent of subjects in clinical trials is protected in the EU Clinical Trials Regulation, ${ }^{37}$ and the GDPR requires explicit and informed consent to the processing of personal health data. ${ }^{38}$ Last, the right to informed consent in relation to cross-border health care is protected in Directive 2011/24/EU. ${ }^{39}$ Nonetheless, jurisprudence of the Court of Justice of the European Union (CJEU) contains few cases concerning the right to informed consent in relation to medical contexts. ${ }^{40}$ Therefore, the EU offers limited protection to the right to informed consent.

At the level of the Council of Europe, however, the right to informed consent is more extensively protected, in particular in the European Convention on Human Rights (ECHR) ${ }^{41}$ the European Convention on Human Rights and Biomedicine (Oviedo Convention $)^{42}$ and the jurisprudence of the European Court of Human Rights (ECtHR). This has important implications for the level of protection of informed consent in the EU. While the EU is not directly bound by the ECHR and the ECtHR's case law, the EU acknowledges that many of the rights enshrined in the CFR correspond to those in the ECHR and shall have the same meaning and scope. ${ }^{43}$ Furthermore, the ECHR is part of the general principles of EU law and can therefore be applied indirectly by the CJEU. ${ }^{44}$ On top of that, while the Oviedo Convention cannot be enforced by the ECtHR, it is frequently referred to by the ECtHR and used as an interpretation tool to the ECHR and national legislation. ${ }^{45}$ As a result, the ECtHR's case law on the right to informed consent can be applied to both Member States and EU institutions. ${ }^{46}$

\footnotetext{
36 A de Ruijter, "The Impediment of Health Laws in Values in the Constitutional Setting of the EU" in TK Hervey et al (eds), Research Handbook on EU Health Law and Policy (Cheltenham, Edward Elgar 2017) pp 486-487.

37 Regulation (EU) No 536/2014 of the European Parliament and of the Council of 16 April 2014 on clinical trials on medicinal products for human use, and repealing Directive 2001/20/EC (Text with EEA relevance) [2014] OJ L 158/1; Flear, supra, note 6, pp 226-230; ML Flear, "Clinical Trials Abroad: The Marketable Ethics, Weak Protections and Vulnerable Subjects of EU Law" in A Albors-Llorens et al (eds), Cambridge Yearbook of European Legal Studies, Vol 16 2013-14 (Oxford, Hart Publishing 2014) pp 89-94.

38 Art 9 GDPR.

39 Directive 2011/24/EU of the European Parliament and of the Council of 9 March 2011 on the application of patients' rights in cross-border healthcare [2011] OJ L 88/65, Art 4.

40 The CJEU did, however, rule on the right to informed consent in relation to medical data, see C-101/01 Lindqvist [2003] I-12992.

41 The European Convention on Human Rights (4 November 1950).

42 Convention for the Protection of Human Rights and Dignity of the Human Being with regard to the Application of Biology and Medicine: Convention on Human Rights and Biomedicine (Oviedo: 4 April 1997).

43 Art 52 (3) CFR.

44 See for example C-377/98 The Netherlands v Parliament and Council of the European Union [2001] I-07079 at para 70 .

45 Charter of Fundamental Rights of the European Union [2000] OJ C 264/01; Convention for the Protection of Human Rights and Dignity of the Human Being with regard to the Application of Biology and Medicine: Convention on Human Rights and Biomedicine (Oviedo, 4 April 1997); Herman Nys, "The European Convention on Human Rights and Biomedicine: A European Patient Rights Instrument" < www.coe.int/t/dg3/healthbioethic/ Activities/10th_Anniversary/Herman\%20Nys.pdf > accessed 4 December 2019.

46 J Krommendijk, "The Use of ECTHR Case Law by the CJEU after Lisbon: The View of the Luxembourg Insiders" (2015) 22(6) Maastricht Journal of European and Comparative Law 815
} 
The ECHR does not directly refer to the right to informed consent, but Article 8 protects the right to respect for private life and Article 10 protects the right to receive and impart information. The Oviedo Convention also incorporates the right to informed consent. ${ }^{47}$ The ECtHR has repeatedly ruled on the right to informed consent, mostly in relation to Article 8 ECHR. In Lambert and others $v$ France, the ECtHR stated that the principle of consent to medical care is one of the aspects of the right to respect for private life. ${ }^{48}$ In Pretty $v$ the United Kingdom, the ECtHR considered that "the imposition of medical treatment, without the consent of a mentally competent adult patient, would interfere with a person's physical integrity". ${ }^{49}$ In Trocellier v France, the ECtHR observed that Contracting States have the positive obligation under Article 8 ECHR to take appropriate measures to ensure respect for patients' physical integrity, and emphasised the importance for individuals facing health risks of having access to information enabling them to assess those risks in order to give informed consent. ${ }^{50}$ In $Z v$ Finland, the ECtHR stated, with respect to the disclosure of a patient's personal health data, that "the disclosure of such data may dramatically affect his or her private and family life $(\ldots)$ ". ${ }^{51}$ In exceptional cases, denial of the right to informed consent can result in a breach of Article 3 ECHR, the absolute right to protection from degrading or inhuman treatment. ${ }^{52}$

Although aforementioned legislation and jurisprudence shows the importance of the right to informed consent in a medical context in the EU legal order, the right is not absolute. Interferences with the right to informed consent based on Article 8 ECHR can be justified when "in accordance with the law", "necessary in a democratic society" and in the interests of the objectives as set out in the article, such as public safety and the protection of health. Furthermore, the interference must be "proportionate to the legitimate aim pursued". 53 While the outbreak of an infectious disease may legitimise restriction of a patient's right to informed consent, the ECtHR has not (yet) ruled on legitimate interference with the right to respect for private life on grounds of the protection of public health emergencies. ${ }^{54}$

In conclusion, with regard to pandemic preparedness and response policy, this means both EU institutions and individual Member States must integrate human rights considerations in their policies when these policies may restrict the right to informed consent, such as in case of EU policies constituting the obligation upon Member States to report cross-border threats to health or perform compulsory medical examination. While the right to informed consent is not absolute, and

\footnotetext{
47 Preamble, Arts 5, 10(1) and 10(2), Oviedo Convention.

48 Lambert and others $v$ France App no 46043/14 (ECHtR, 5 June 2015) at para 74.

49 Pretty $v$ the United Kingdom App no 2346/01 (ECtHR, 29 April 2002) at para 63.

50 Trocellier $v$ France App no 75725/01 (ECtHR, 5 October 2006) at para 4.

51 Zv Finland App no 22009/93 (ECtHR, 25 February 1997) at para 96. Also see $Y v$ Turkey App no 648/10 (ECtHR, 17 February 2015) at paras 68-78 and CC v Spain App no 1425/06 (ECtHR, 6 October 2009) at para 33.

52 MK Addo and N Grief, "Does Article 3 of The European Convention on Human Rights Enshrine Absolute Rights?" (1998) 9 European Journal of International Law 510; VC v Slovakia App no 18968/07 (ECtHR, 8 November 2011) at paras 116-120.

53 See Art 8 (2) ECHR; S Greer, The Exceptions to Article 8 to 11 of the European Convention on Human Rights (Strasbourg, Council of Europe Publishing 1997) p 15.

54 ibid.
} 
serious cross-border threats to health can be a valid reason to derogate from the right, interference must be legitimate. As a result, both at the EU and national level, the individual right to informed consent should be taken into account in the shaping of pandemic preparedness and response policies, which could often result in the balancing of informed consent against the common good of public health.

\section{Legal CASE Study on the 2013-2016 Ebola outbreak: the Right to INFORMED CONSENT IN EU PANDEMIC POLICIES IN THE NETHERLANDS}

This section will review national pandemic policies and laws in the Netherlands, with specific regard to the 2013-2016 Ebola outbreak. The aim of this case study is to establish how EU supranational pandemic policies, aimed at preparedness and response to pandemic outbreaks on the EU territory, have impacted Dutch national pandemic policies. The findings will be used to explore the legal possibility for safeguarding informed consent if case pandemic response measures had been taken in light of the 2013-2016 Ebola outbreak.

\section{EU Countermeasures during the 2013-2016 outbreak of Ebola}

In reaction to the 2013-2016 Ebola outbreak in West Africa, the EU took action at several levels. First, a EU Ebola Coordinator was appointed and an EU Ebola Task Force was established under the Emergency Response Coordination Centre (ERCC) in order to strengthen coordination between the EU institutions and Member States. ${ }^{55}$ The EMA set up an ad hoc Ebola task force and designed mechanisms to speed up development of Ebola treatment and vaccines such as rapid scientific advice and fast track approval. ${ }^{56}$ Furthermore, the ECDC performed rapid risk assessments and communicated epidemiological updates and other information. ${ }^{57}$ Moreover, the ECDC published, inter alia, guidelines on medical evacuation flights to Europe for patients with Ebola virus disease, recommendations on entry and exit screening measures, and guidelines on public health management of persons that had been in direct contact with Ebola in the EU. ${ }^{58}$ These guidelines include recommendations on the isolation of infected persons, temperature screening in airports, contact listing, contact tracing and monitoring of possibly exposed persons (contact persons). Contact tracing is not restricted to persons who have had direct contact with (bodily fluids of) an Ebola patient, but includes persons who have shared a seating area in public transportation or aeroplane or had classroom or office contact with an Ebola patient.

\footnotetext{
55 European Commission, "EU Response to the Ebola Outbreak" (17 October 2014) <ec.europa.eu/europeaid/ regions/africa/west-africa/ebola-response_en> accessed 4 December 2019.

56 EMA, "Speeding up Development of Ebola Treatments and Vaccines" <www.ema.europa.eu/ema/index.jsp? curl=pages/news_and_events/news/2014/10/news_detail_002190.jsp\&mid=WC0b01ac058004d5c1 >accessed 4 December 2019.

57 ECDC, "Rapid Risk Assessment: Outbreak of Ebola virus disease in West Africa" (1 August 2014).

58 ECDC, "Assessing and planning medical evacuation flights to Europe for patients with Ebola virus disease and people exposed to Ebola virus" (ECDC, 21 October 2014); ECDC, "Infection prevention and control measures for Ebola virus disease. Entry and exit screening measures" (ECDC, 12 October 2014); ECDC, "Public health management of persons having had contact with Ebola virus disease cases in the EU" (ECDC, 22 October 2014).
} 
For contacts with "high risk exposure", the ECDC recommended active monitoring (monitoring of temperature and symptoms twice a day) by public health authorities for 21 days after last exposure, a travel ban and laboratory testing. ${ }^{59}$

All EU Member States have an obligation under EU and international law to develop procedures with regard to preparing and responding to future "serious cross-border threats to health" such as pandemics. ${ }^{60}$ Furthermore, in practice, they will often implement EU policies at the national level. ${ }^{61}$ Therefore, the aforementioned countermeasures could impact on individual fundamental rights, the right to informed consent in particular, in EU Member States. Medical countermeasures such as fast track approval may impact on informed consent when antivirals and vaccines are prescribed based on limited information. ${ }^{62}$ Soft countermeasures, such as recommendations on entry screening, can interfere with both the right to integrity of the person and the right to respect for private life. ${ }^{63}$ Surveillance countermeasures, like exchanging contact tracing data between Member States, can interfere with the right to respect for private life and, if it is unclear who receives the information or explicit consent is not given, with the right to informed consent. ${ }^{64} \mathrm{EU}$ law and policy does not seem to contain specific safeguards on how to properly balance the protection of individual fundamental rights such as the right to informed consent with the protection of public health, therefore leaving it up to the Member States to determine a proportional balance.

\section{National pandemic policies in the Netherlands}

In the Netherlands, the most important public law powers with regard to the control of infectious diseases are laid down in the Public Health Act (Wpg), which has incorporated the International Health Regulations. ${ }^{65}$ The Wpg distinguishes four categories of infectious diseases. Depending on the category, the Wpg empowers public authorities to adopt different types of measures to respond to infectious disease outbreaks. ${ }^{66}$ Furthermore, the National Institute for Public Health and the Environment (RIVM) has adopted a general national action plan on infectious disease emergencies. ${ }^{67}$ The Centre for Infectious Disease Control (CIb) of the RIVM coordinates national responses to infectious diseases and serves as National Focal Point to the ECDC.

In reaction to the Ebola outbreak in West Africa, the CIb put an extensive action plan in place to prevent and prepare for a national Ebola outbreak in October 2014, consisting of

\footnotetext{
59 ibid.

60 See the EU Health Threats Decision and World Health Assembly, "International Health Regulations" (Geneva, World Health Organisation 2005) Arts 5 and 6.

61 De Ruijter, supra, note 6, pp 149-150.

62 ibid, pp 147-148.

63 ibid, pp 48-50, 143-149.

64 P Dąbrowska-Kłosińska, "Tracing Individuals under the EU Regime on Serious, Cross-Border Health Threats: An Appraisal of the System of Personal Data Protection” (2017) 8 EJRR 700; Art 7 CFR.

65 RIVM, Draaiboek International Health Regulations (2009) <lci.rivm.nl/draaiboeken/international-healthregulations-ihr> accessed 4 December 2019.

66 J Dute and A Hendriks, "Recht in tijden van Mexicaanse griep" (2009) 35 NJB 1710-1712.

67 Translation of Rijksinstituut voor Volksgezondheid en Milieu; RIVM, Generiek Draaiboek Infectieziektebestrijding (2014) <lci.rivm.nl/draaiboeken/generiek-draaiboek> accessed 4 December 2019.
} 
"soft", "medical" and "surveillance" countermeasures. Measures included the establishment of an Ebola Information Point, the providing of training to hospital and ambulance personnel, the implementation of new legislation in order to make it possible to use unregistered experimental medicines and vaccines in the treatment of Ebola and guidelines on isolation of probable Ebola patients and contact tracing of probable contact persons. ${ }^{68}$

\section{Impact of EU coordination on the right to informed consent}

As outlined previously, the right to informed consent is protected at the EU level. The right to informed consent is furthermore protected at the national level in the Dutch Civil Code, the Medical Research Involving Subjects Act and several protocols and guidelines issued by medical associations and health care institutions. ${ }^{69}$

\section{a. De jure and de facto impact on Dutch pandemic policies}

Dutch policies on pandemic preparedness and response, Ebola policies specifically, are substantially shaped by EU and international laws and policies, both de jure and de facto. In this context, de jure impact means that EU policies have a direct or explicit effect on national policies and laws, arising from legal obligations. In contrast, de facto impact means that EU policies have an indirect or implicit effect on national policies and laws, not being the direct effect of legal obligations. This distinction is made because the legislative competence of the EU is limited in the field of health, and EU health policy rarely imposes obligations on national governments. ${ }^{70}$

Dutch pandemic policies are to some extent de jure shaped by EU policies. First, Decision 1082/2013/EU is binding upon the Netherlands. ${ }^{71}$ As a result, the $\mathrm{CIb}$ is obliged to notify an alert in the Early Warning and Response System (EWRS) in the case of potential serious cross-border threats to health such as the occurrence of Ebola. ${ }^{72}$ The EWRS is a tool for monitoring public health threats in the EU. ${ }^{73}$ Under the EWRS, the exchange of information on the occurrence of and response to communicable diseases between the Member States and the European Commission is regulated. To determine whether notification is necessary, the CIb has adopted the procedure prescribed by the European Commission. ${ }^{74}$ Additionally, the Dutch

\footnotetext{
68 Besluit van de Minister van Volksgezondheid, Welzijn en Sport van 12 september 2014, kenmerk 664010-126012WJZ, houdende verlening van een ontheffing ex artikel 40, derde lid, onderdeel g, van de Geneesmiddelenwet, aan het RIVM; JT Van Dissel et al, "Ebola - hoe is Nederland voorbereid?" (2014) 5 Magazine nationale veiligheid en crisisbeheersing 29-31.

69 Art 7:448 (1), 7:450 and 7:457 Civil Code, Art 6 Medical Research Involving Subjects Act.

70 See Art 168 TFEU; De Ruijter, supra, note 6, pp 1-8.

71 Art 288 TFEU.

72 Art 9 EU Health Threats Decision; RIVM, "Bijlage 3. Monitoring contacten ebola- of marburgpatiënt" < lci.rivm. nl/sites/default/files/2017-05/Bijlage\%203.\%20Monitoring\%20contacten.pdf> accessed 4 December 2019.

73 SL Greer, "The European Centre for Disease Prevention and Control: Hub or Hollow Core?" (2012) 37 Journal of Health Politics, Policy and Law 1017.

74 Commission Decision No 2000/57/EC of 22 December 1999 on the early warning and response system for the prevention and control of communicable diseases under Decision No 2119/98/EC of the European Parliament and of the Council (notified under document number C(1999) 4016) [2000] OJ L 21/32, Annex I and II.
} 
government is obliged to send out an alert to the EWRS with "any available relevant information in their possession" and "personal data necessary for the purpose of contact tracing". 75 "Contact tracing" is the tracing of persons who have been infected or who are in danger of being infected and the exchange of "any available relevant information in their possession that may be useful for coordinating the response", 76 including the exchange of personal health data and other personal information via the electronic platform of the EWRS. ${ }^{77}$

Furthermore, Dutch policy on medical research is de jure impacted by the directly applicable EU Clinical Trial Regulation. ${ }^{78}$ The Regulation governs the conducting of clinical trials in the EU. Clinical trials generally play a large role in pandemic policies with relation to the (emergency) development and authorisation of vaccines and antivirals, especially in case of outbreaks of diseases such as Ebola, for which no effective treatments are yet approved. Furthermore, the Regulation contains specific provisions for clinical trials in emergency situations. ${ }^{79}$

More importantly, Dutch pandemic policies are de facto influenced by EU policies such as recommendations and guidelines. The EU takes "soft" countermeasures in the form of general recommendations and guidelines in order to "help Member States and Institutions decide which measures they will apply", such as providing examples of communication strategies and models of pandemic planning and public health measures. ${ }^{80}$ While pointing out the autonomy of Member States, the ECDC emphasises that "some measures are either so self-evident or so ineffective that simply laying out the evidence should make for easy policy decisions". ${ }^{81}$ Although these EU countermeasures are non-binding, the Dutch government tends to implement these recommendations, also in the case of Ebola policies. ${ }^{82}$

In the context of medical treatment, The Netherlands' Ebola action plan is grounded in the ECDC's guidelines on "Public health management of persons having had contact with Ebola virus disease cases in the EU", 83 implementing recommendations on isolation and laboratory testing of infected persons, health monitoring and contact listing and tracing. ${ }^{84}$ The action plan contains an "Ebola response roadmap" that directly links to the ECDC's website. ${ }^{85}$ In addition, the Dutch Ebola case definition is a literal translation of the Ebola case definition issued by the ECDC: the "Ebola virus disease ad hoc case definition for reporting in the EU", stating the clinical criteria

\footnotetext{
75 Art 9 EU Health Threats Decision; Dąbrowska-Kłosińska, supra, note 64.

76 ibid, Arts 9, 16.

77 Dąbrowska-Kłosińska, supra, note 64.

78 EU Clinical Trials Regulation; Art 288 TFEU.

79 Art 35 Clinical Trials Regulation.

${ }^{80}$ ECDC, "Guide to public health measures to reduce the impact of influenza pandemics in Europe: 'The ECDC Menu"” (ECDC 2009).

81 ibid.

82 De Ruijter, supra, note 6, pp 133-135.

83 ECDC, "Public health management of persons having had contact with Ebola virus disease cases in the EU" (ECDC 23 October 2014).

84 RIVM, "Virale hemorragische koorts - filovirussen: richtlijn" < lci.rivm.nl/richtlijnen/virale-hemorragischekoorts-filovirussen> accessed 4 December 2019.

85 RIVM, "Bijlage 1. Stappenplan ebola" < lci.rivm.nl/sites/default/files/2019-09/LCI-richtlijn\%20VHK\% 20filovirussen\%2C\%20bijlage\%201.\%20Stappenplan\%20ebola\%202.pdf > accessed 4 December 2019.
} 
(fever and additional symptoms such as severe headache or multi-organ failure), the laboratory criteria and the epidemiological criteria. ${ }^{86}$ Furthermore, if the 2013-2016 Ebola outbreak had infected more people in Europe, it is likely that the EMA and the ECDC would have issued recommendations on the use of specific vaccines and "at-risk" groups and "target groups" for vaccination. ${ }^{87}$ It is probable that the Netherlands would have implemented these recommendations, considering that during the outbreak of $\mathrm{A}(\mathrm{H} 1 \mathrm{~N} 1)$ Influenza, the Netherlands implemented the EMA's recommendation to use the vaccine "Pandemrix". ${ }^{88}$ In addition, the ECDC's recommendation on "at-risk" groups and "target groups" for vaccination with regard to Pandemic A(H1N1) 2009 Influenza was integrally implemented. ${ }^{89}$

In the context of personal (medical) data processing, the ECDC issued non-binding opinions on how to use contact tracing. ${ }^{90}$ Additionally, the European Commission has adopted a recommendation with an indicative list of personal data that may be exchanged for the purpose of coordination of contact tracing measures under the EWRS. This includes personal information (name, nationality, date of birth, sex, ID specifications, current home address, phone numbers and e-mail address), travel specifications, contact information, information on accompanying persons and emergency contact details. ${ }^{91}$ These soft countermeasures were directly implemented in national strategies. ${ }^{92}$ For instance, the CIb directly implemented the ECDC's guideline on "Risk assessment for disease transmitted on aircraft": the CIb's Ebola guidelines state that "the ECDC guideline $(. .$.$) describes the risk stratification of$ aircraft contacts". 93

In the context of medical research, Dutch policy may be de facto impacted by the EMA's recommendations on compassionate use of unauthorised medicines. Although no recommendations were issued with regard to Ebola medicines, during the outbreak of Influenza A (H1N1), the EMA issued an opinion on the use of unregistered antiviral "Tamiflu i.v.", following which the Dutch Medicines Evaluation Board

\footnotetext{
86 See ECDC, "Ebola virus disease ad hoc case definition for reporting in the EU", <www.ecdc.europa.eu/en/ all-topics-zebola-and-marburg-feversthreats-and-outbreaksebola-outbreak-west-africa-2013-2016/ebola >accessed 4 December 2019; RIVM, "Bijlage 2. Casusdefinities marburg en ebola" <lci.rivm.nl/richtlijnen/viralehemorragische-koorts-filovirussen $>$ accessed 4 December 2019.

87 The WHO used the investigational Ebola vaccine "rVSV-ZEBOV" in West Africa, see A Gulland, "WHO ready to deploy Ebola vaccine in disease outbreak" (2017) BMJ 357.

88 EMA, "Medicines authorised during pandemic" <www.ema.europa.eu/ema/index.jsp?curl=pages/special_ topics/general/general_content_000251.jsp\&mid=WC0b01ac05801db932>accessed 4 December 2019.

89 RIVM, "Influenza Richtlijn” < lci.rivm.nl/richtlijnen/influenza> accessed 4 December 2019.

90 ECDC, "Assessing and planning medical evacuation flights to Europe for patients with Ebola virus disease and people exposed to Ebola virus" (ECDC 21 October 2014); ECDC, "Infection prevention and control measures for Ebola virus disease. Entry and exit screening measures" (ECDC 12 October 2014); ECDC, "Public health management of persons having had contact with Ebola virus disease cases in the EU" (ECDC 22 October 2014).

91 Commission Recommendation (EU) 2017/1140 of 23 June 2017 on personal data that may be exchanged through the Early Warning and Response System (EWRS) established pursuant to Decision No 1082/2013/EU of the European Parliament and of the Council for the purposes of the coordination of contact tracing measures in relation to serious crossborder threats to health (notified under document C(2017) 4197) (Text with EEA relevance) [2017] OJ L 164, pp 65-67.

92 See the RIVM's Ebola action plan: RIVM, "Virale hemorragische koorts - filovirussen: richtlijn" <lci.rivm.nl/ richtlijnen/virale-hemorragische-koorts-filovirussen> accessed 4 December 2019.

93 ECDC, "Risk assessment guidelines for infectious diseases transmitted on aircraft" (ECDC, 20 May 2014); RIVM, "Virale hemorragische koorts - filovirussen: richtlijn" < lci.rivm.nl/richtlijnen/virale-hemorragische-koortsfilovirussen> accessed 4 December 2019.
} 
decided to allow the antiviral for compassionate use as well. ${ }^{94}$ In light of the influential role of the EMA and the severity of Ebola it is probable that the Netherlands would have done the same if a recommendation on an unauthorised Ebola medicine had been issued.

\section{b. De jure and de facto impact on the right to informed consent in the Netherlands}

Public health and individual rights are often in conflict and need to be appropriately balanced. Countermeasures taken by the EU to prevent and combat infectious disease can deeply impact the day-to-day lives of EU citizens and potentially interfere with their individual rights. EU countermeasures are grounded in the notion that serious cross-border threats to health legitimise the restriction of individual freedoms in order to serve the common good - public health. One of the individual rights that potentially conflicts with the interest of public health is the individual's right to informed consent, which requires five conditions: voluntarism, capacity, understanding, disclosure and decision.

In the context of medical treatment, de facto impact on the right to informed consent can be determined in relation to a possible ECDC recommendation on the implementation of exit screening. ${ }^{95}$ Exit screening can be undertaken through questionnaires or the use of thermal image scanners. ${ }^{96}$ Exit screening may impact the right to informed consent in the Netherlands in two ways. First, the use of questionnaires may impact the right to informed consent in relation to the sharing of personal (medical) data, because the passenger may not have had full disclosure on the objectives or did not understand the implications for his personal situation. Second, the scanners used for exit passenger screening may have implications for the passenger's health due to radiation effects. The EU regulates the safety of screening devices. ${ }^{97}$ The ECDC's recommendation remains silent about informed consent: it does not state whether and under what circumstances passengers may refuse the exit screening. Thus, an EU recommendation to implement exit screening may have implications for the right to informed consent, since passengers may not have had full disclosure on the health risks, did not completely understand the implications for their personal situations, did not actively make a decision on whether to undergo exit screening or did not voluntarily consent to the procedure, but rather were coerced or pressured by the airport personnel to undergo the procedure. ${ }^{98}$

94 EMA, "Conditions of use, conditions for distribution and patients targeted and conditions for safety monitoring addressed to member states for IV Tamiflu available for compassionate use" (27 September 2011) <www.ema.europa.eu/docs/en_GB/document_library/Other/2010/01/WC500069899.pdf > accessed 4 December 2019; CBG, "Overzicht van goedgekeurde compassionate use programma's" (2018) <www.cbg-meb.nl/mensen/bedrijvengeneesmiddelen-voor-mensen/documenten/publicaties/2018/01/01/compassionate-use-programmas $>$ accessed 4 December 2019.

95 ECDC, "Infection prevention and control measures for Ebola virus disease. Entry and exit screening measures" (ECDC 12 October 2014).

96 LA Selvey et al, "Evaluation of Border Entry Screening for Infectious Diseases in Humans" (2015) 21(2) Emerging Infectious Diseases 197.

97 Commission Implementing Regulation (EU) 2015/1998 of 5 November 2015 laying down detailed measures for the implementation of the common basic standards on aviation security (Text with EEA relevance) [2015] OJ L 299, pp 1-142.

98 De Ruijter, supra, note 6. 
Furthermore, the implementation of the EMA's recommendations to use specific pandemic vaccines can de facto impact the right to informed consent in the medical treatment context. To illustrate, research on the use of the "Pandemrix" vaccine during the $\mathrm{A}(\mathrm{H} 1 \mathrm{~N} 1)$ pandemic, as recommended by the EMA, suggests an increased risk of narcolepsy. ${ }^{99}$ Parents of children that had used this were not informed about this risk. ${ }^{100}$ It can be said that if the side-effects of a pandemic vaccine were known or it has not been sufficiently tested, this may have implications for the right to informed consent, because the patients may not have had full disclosure on the health risks or may not have had complete understanding of the implications for their personal situation. This risk is common to pandemic vaccines because generally clinical data is limited due to time constraints. ${ }^{101}$ However, the EMA does not provide guidance in how to handle this risk in its recommendations.

In addition, the right to informed consent in the context of medical treatment could possibly be affected by the implementation of the ECDC's recommendations on "at-risk" and "target" groups for pandemic vaccination. Although the effects of this type of recommendation are generally limited because the Dutch government has never implemented compulsory vaccination, the recommendation of vaccination to specific groups can still lead to decisions without informed consent, because the identification as "at-risk" or "target" may scare patients into undergoing the vaccination and refrain them from voluntarily making a decision. ${ }^{102}$ The ECDC's recommendation does not acknowledge this effect and the implications for informed consent.

In the context of participation in medical research, the right to informed consent is de jure impacted by the EU Clinical Trial Regulation. The Regulation puts informed consent of the research subject at the basis of every clinical trial but provides for an exception with regard to emergency situations. In emergency situations, caused by a sudden serious medical condition, informed consent may be obtained after the inclusion of the patient in the clinical trial, when prior informed consent is impossible. ${ }^{103}$ This means that in case of a critically ill patient suffering from Ebola, the patient can be included in emergency medical research without exercising his right to informed consent. However, it can be said that the EU Regulation provides for sufficient safeguards to protect the right to informed consent, as it requires inter alia the impossibility of prior informed consent or informed consent by proxy, a severe medical condition and minimal risks, making clinical research without informed consent into a last resort option. ${ }^{104}$ Moreover, informed consent plays an

99 EMA, "CHMP Type II variation assessment report" (26 June 2014) <www.ema.europa.eu/docs/en_GB/ document_library/EPAR_-_Assessment_Report_-_Variation/human/000832/WC500175146.pdf $>$ accessed 4 December 2019.

100 T Mudde, "Staat gedaagd voor bijwerking vaccin Mexicaanse griep" de Volkskrant (Amsterdam, 1 September 2016) <www.volkskrant.nl/g-be089313>accessed 4 December 2019.

101 WHO, "Safety of pandemic vaccines" (6 August 2009) <www.who.int/csr/disease/swineflu/notes/ h1n1_safety_vaccines_20090805/en/>accessed 4 December 2019.

102 A high compliance with H1N1 vaccination was recorded among care providers, see F Blasi et al, "Compliance with Anti-H1N1 Vaccine among Healthcare Workers and General Population" (2012) 18 Clinical Microbiology and Infection 37.

103 Art 35 EU Clinical Trials Regulation.

104 EJO Kompanje et al, "Medical research in emergency research in the European Union member states: Tensions between theory and practice" (2014) 40(4) Intensive Care Medicine 496. 
important role throughout the whole EU Clinical Trials Regulation: it contains an extensive set of rules for the protection of subjects, with special regard to incapacitated persons and minors. ${ }^{105}$ Additionally, it specifically refers to the importance of human dignity, the integrity of the person and respect for private life. ${ }^{106}$

Furthermore, informed consent may be de facto impacted by the EMA's recommendations on compassionate use. The EMA can issue recommendations on compassionate use of unauthorised medicines, making medicines in development available to patients who have a severe disease with no satisfactory authorised therapies and who cannot enter clinical trials. ${ }^{107}$ Neither the legal basis for compassionate use nor the EMA's website mention the importance of informed consent of the patients involved. ${ }^{108}$ The European Commission does, however, acknowledge the need to increase transparency on compassionate use on the EU level by supporting the availability of key information on informed consent requirements on the EMA website. ${ }^{109}$ It is questionable whether the conditions of voluntarism and capacity are met when the patient is in a desperate medical emergency. ${ }^{110}$ Furthermore, the patient may not have had full disclosure on the health risks, because data on efficacy and safety are limited, and he may not have had complete understanding of the implications for his personal situation, because he did not have the knowledge necessary to evaluate the scarce data. ${ }^{111}$

The impact of EU pandemic policies on the right to informed consent is the most significant in the field of processing of personal (medical) data. The Dutch Government is required to share (medical) information on confirmed cases of listed infectious diseases and personal information needed for the tracing of contacts through the EWRS with public authorities throughout the whole EU and personal data may even be transferred to the WHO and third countries party to the International Health Regulations. ${ }^{112}$ The EU Health Threats Decision does not clarify whether patients and contacts should be asked for permission to share personal data. The GDPR, however, provides for a public health exception to the authority to process personal data concerning health. In such a case, informed consent by the data subject to the exchange of their personal (health) data with one or more Member States is not necessary. Informing the patient of the processing activities must take

\footnotetext{
105 Arts 28, 29, 30 and 35 EU Clinical Trials Regulation; Flear, supra, note 6, pp 226-230.

106 Recital 83, EU Clinical Trials Regulation.

107 Regulation (EC) No 726/2004 of the European Parliament and of the Council of 31 March 2004 laying down Community procedures for the authorisation and supervision of medicinal products for human and veterinary use and establishing a European Medicines Agency [2004] OJ L 136.

108 Regulation (EC) No 726/2004 of the European Parliament and of the Council of 31 March 2004 laying down Community procedures for the authorisation and supervision of medicinal products for human and veterinary use and establishing a European Medicines Agency (Text with EEA relevance) [2004] OJ L 136, p 1, Art 83; EMA, "Compassionate use", <www.ema.europa.eu/en/human-regulatory/research-development/compassionate-use > accessed 4 December 2019.

109 European Commission, "STAMP Commission Expert Group, Compassionate use programmes” (10 March 2016) <ec.europa.eu/health/sites/health/files/files/committee/stamp/2016-03_stamp4/6_compassionate_use_background_ paper.pdf $>$ accessed 4 December 2019.

110 J Borysowski et al, "Ethics review in compassionate use" (2017) 15 BMC Medicine 136.

111 ibid.

112 DG Health and Food Safety, "DPO-2794.5 "Early Warning and Response System (EWRS)" (2014) $<$ ec.europa.eu/dpo-register/details.htm?id=43430> accessed 4 December 2019.
} 
place, unless this is impossible or involves disproportionate effort. ${ }^{113}$ Furthermore, the patient does not have the right to erasure of personal data when the processing is necessary for public health purposes. ${ }^{114}$ The European Commission has emphasised that processing through the EWRS is authorised in case of pandemic threats, for reasons of substantial public interest. ${ }^{115}$ As a result, the right to informed consent may be limited due to not meeting the conditions of decision, understanding and disclosure when the patient may not have been at all informed about the processing of personal (health) data. Additionally, the patient may not have consented to the sharing of information through the EWRS or may not have understood the implications for his personal situation and the scope of the data processed. For example, the patient or contact of the patient may not be aware of the fact that his personal data was shared with public health authorities in other Member States. Even if he is informed of the identity of the receiving parties, he may not know the scope of personal data processed or know how to exercise his right to rectification in case of incorrect information. ${ }^{116}$

In conclusion, Dutch laws and policies on pandemic preparedness and response, Ebola policies specifically, are shaped by EU forces, both de jure and de facto. More importantly, it can be concluded that EU pandemic policies may have implications for the right to informed consent in the Netherlands. While these interferences with the right to informed consent may be legitimate in light of the protection of public health, this case study does show that public health interests and individual rights are in fact balanced at the EU level, which has consequences for the protection of the individual's right to informed consent.

\section{Conclusion}

The development of EU policies and laws on pandemics is grounded in the notion that communicable diseases do not respect borders, and outbreaks can only efficiently be combatted if countries cooperate. The main responsibility for the drafting of national public health policies lies with the individual Member States. In the fight against serious cross-border threats to health such as pandemics, the possibility for the EU to take formal action is limited. Nevertheless, it can be concluded from the case study on the Netherlands that Member States' national pandemic preparedness and response strategies are substantially shaped by EU actions, both de jure and de facto. On top of that, it can be said that this EU influence has implications for individual rights in the Member States, in particular the right to informed consent. Consequently, the first important conclusion is that EU policies have implications for a crucial part of individual EU citizens' lives, namely decision-making autonomy over their own bodies, and, more generally, their own health.

\footnotetext{
113 Art 9(i) and 14(5)(b) GDPR.

114 Art 17(3)(c) GDPR.

115 ibid.

116 Dąbrowska-Kłosińska, supra, note 64.
} 
This conclusion places the long-running debate on the balance between public health and individual fundamental rights in a different perspective: it is generally accepted that a national government can restrict its citizens' rights to a certain degree in order to protect the health of the public, but what if these restrictions are the effect of EU forces? Therefore, an important question is how the right to informed consent is safeguarded in the context of EU and international policy on pandemic preparedness and response in the EU.

Countermeasures issued by the EU, such as recommendations on contact tracing, may limit the right to informed consent. While limitation of individuals' right to informed consent may be legitimate in the event of pandemic outbreaks, interferences do nevertheless have to be necessary, proportionate, in the interest of the protection of public health and in accordance with the law. This complex decision on balancing public health and individual rights with respect to these measures is not mentioned at all by the EU in its countermeasures. From its recommendations, it seems that the protection of public health is given priority over the protection of individual rights, but the underlying principles and choices are not made explicit. In other pandemic countermeasures, such as the EU Clinical Trial Regulation's emergency exception and the GDPR's requirement to inform the data subject in cases of contact tracing, the EU leaves the balancing of interests up to the Member States, providing guidelines by describing the circumstances in which derogation from the right to informed consent is allowed. However, the extent of the exceptions remains unclear, allowing the Member States a wide margin of appreciation in deciding to what extent the individual's right to informed consent must be protected.

In the end, the ultimate decision on how to comply with EU pandemic policies in order to adequately balance the right to informed consent and the protection of public health remains with the Member States. It is up to the individual Member States to carefully review the extent to which the protection of individual rights is outweighed by the necessity to protect the common good. However, in order to safeguard the right to informed consent in pandemic preparedness and response policies throughout the EU, it would be beneficial to all EU citizens if the EU integrated fundamental rights considerations in its pandemic policies to provide insight into the underlying principles and choices. This would provide the Member States with some guidance on how to balance the various interests at stake in public health emergencies and would, in all likelihood, lead to a more exhaustive inclusion of fundamental rights considerations in national pandemic preparedness and response policies. 